\title{
Giải Pháp Phòng Ngừa Rủi Ro Tỷ Giá Bằng Công Cụ Tài Chính Phái Sinh Tại Ngân Hàng Thương Mại Cổ Phần Sài Gòn Thương Tín
}

\author{
Bùi Nhất Vương \\ Trường Đại học Ngoại ngữ - Tin học Tp. HCM
}

\section{Tóm tắt}

Công cụ tài chính phái sinh là một sản phẩm dịch vụ hiện đại phổ biến trên thị trường thế giới. Ngoài đặc trưng là kênh đầu tư mang lại hiệu quả, công cụ phái sinh còn là kênh phòng ngừa rủi ro hữu hiệu. Thông qua nghiên cứu của đề tài về phòng ngừa rủi ro tỷ giá tại ngân hàng TMCP Sacombank, tác giả nhận thấy tác động của sự biến động tỷ giá đến tình hình doanh nghiệp, những lợi ích rất lớn về ứng dụng công cụ phòng ngừa rủi ro tỷ giá. Tuy nhiên, việc áp dụng này còn nhiều hạn chế, trình độ hiểu biết khiêm tốn, mức độ phổ biến thấp và việc áp dụng chưa nhiều. Do đó, việc phổ biến áp dụng loại hình này sẽ mang lại nhiều lợi ích cho doanh nghiệp, ngân hàng và nền kinh tế nói chung.

Tù khóa: Rủi ro tỷ giá, tài chính phái sinh, Sacombank. 